\title{
НАЦІОНАЛЬНАІ РЕГІОНАЛЬНАЕКОНОМІКА
}

УдК 332.1:338.45(477)

ВоЛОдимИР ЗАХАРЧЕНКО

\section{КАПІТАЛЬНІ ІНВЕСТИЦЇ ЯК ДРАЙВЕР ТЕХНОЛОГІЧНОЇ РЕСТРУКТУРИЗАЦІї ПРОМИСАОВОСТІ УКРАЇНИ ТА Ї̈ РЕГІОНІВ У ПОСТІНДУСТРІАЛЬНУ ЕПОХУ}

Обгрунтовано необхідність технологічноїреструктуризації промисловості Украӥни та їі регіонів у постіндустріальну епоху. Розкрито значення капітальних інвестицій для випереджуючого розвитку новітніх видів промислової діяльності. Відповідно до методологічних установок щодо структуризації промисловості країни та їі регіонів на основі технологічного рівня (за технологічними укладами), представлено авторський методичний підхід, що включає як базові елементи структурного аналізу, так $i$ спеціальні, пов'язані з використанням коефріцієнта Хечмена. Проаналізовано динаміку і структуру капітальних інвестицій та їх вплив на обсяги реалізованої продукції в Україні та їі регіонах у розрізі окремих видів промислової діяльності різного технологічного рівня. Визначено стратегічні напрями технологічної реструктуризації промисловості України та ії регіонів у постіндустріальну епоху, які передбачають удосконалення соціально-політичних інститутів українського суспільства та проведення виваженої державної промислової політики. 3 метою формування постіндустріальної технологічної структури промисловості України та ії регіонів відмічено доцільність нарощування обсягів капітальних інвестицій, а також їх перерозподілу на користь новітніх видів промислової діяльності.

Ключові слова: постіндустріальна епоха, промисловість (України, регіонів), технологічний уклад, технологічна структура, вид промислової діяльності, капітальні інвестииії, реструктуризація.

JEL O 14, 18; R 11, 58

Постановка проблеми. Світова енергетична криза 1970-х років поставила людство перед необхідністю переходу від індустріальної (ресурсовитратної, еконебезпечної) до постіндустріальної (ресурсоощадливої, екобезпечної) економіки. Ця епохальна трансформація в історії людства знайшла відображення у концепції постіндустріального суспільства Д. Белла [1].

Д. Белл визначає постіндустріальне суспільство як суспільство, в економіці якого базу формує не виробництво товарів, а продукування послуг. При цьому наука розглядається якпередумова інноваційного оновлення економіки й побудови нової структури суспільства, в якій клас технічних спеціалістів стає основною професійною групою.

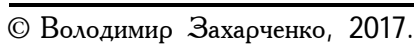


Україна уже в середині 70-х років (в складі колишнього СРСР) мала достатні передумови для побудови економіки постіндустріального типу. В той період СРСР і США мали приблизно однаковий потенціал новітніх галузей (переважно військово-промислового комплексу). Але як тільки у США та інших країнах Заходу сформувався потужний сектор із виробництва високотехнологічних споживчих товарів (комп'ютерів, аудіовізуальної техніки тощо), відставання від них почало наростати. В результаті до початку 1990-х років провідні країни світу (США, Японія, Німеччина та ін.) створили основи постіндустріальної економіки, тоді як Україна все ще стоїть перед необхідністю їі створення.

Постіндустріальний імператив у розвитку економіки й, зокрема, промисловості України та її регіонів безумовно передбачає їх технологічну реструктуризацію - зростання у її структурі частки високотехнологічних видів промислової діяльності (ВПД). Зрозуміло, що цього можна досягти тільки переорієнтувавши і збільшивши обсяги капітальних інвестицій у новітні ВПД.

Аналіз останніх досліджень і публікацій. Концептуальні засади технологічної реструктуризації промисловості України таїі регіонів в постіндустріальну добу обґрунтовані у працях таких вітчизняних учених, як: О. Амоша, Ю. Бажал, В. Вишневський, В. Геєць, Л. Дейнеко, Я. Жаліло, С. Захарін, Л. Збаразська, Ю. Кіндзерський, В. Ляшенко, А. Мельник, О. Мельник, І. Одотюк, О. Саліхова, В. Стадник, Л. Федулова, Л. Шинкарук, М. Якубовський та ін.

Питанням оцінки та аналізу капітальних інвестицій як драйвера (рушійної сили) технологічної реструктуризації промисловості України та її регіонів присвячені праці І. А. Шовкун [2, с. 243-276] та фахівців Національного інституту стратегічних досліджень [3]. Однак у них відсутній диференційований аналіз капітальних інвестицій в розрізі ВПД різного технологічного рівня.

Мета дослідження. Показати вплив капітальних інвестицій на зрушення в технологічній структурі промисловості України таїі регіонів у контексті постіндустріальних трендів розвитку.

Виклад основного матеріалу дослідження. Технологічну структуру промисловості країни та її регіонів характеризують співвідношення між: 1) ВПД, що мають різний технологічний рівень (належать до різних технологічних укладів); 2) сегментами, що визначають науково-технічний прогрес і рештою сегментів; 3) сегментами з виробництва інноваційної та неінноваційної продукції. Базовим, звичайно, є перше співвідношення.

Постіндустріальний розвиток, згідно з техніко-економічної парадигми К. Фрімена та К. Перес, знаменують п'ятий і наступний технологічні уклади. При цьому під технологічним укладом розуміється сукупність взаємопов'язаних виробництв, що мають приблизно однаковий технічний рівень і розвиваються синхронно на основі певного ключового фрактора, який революціонізує технологічну структуру економіки й, передусім, промисловості [4, с. 11].

Якщо ключовими фракторами третього технологічного укладу була електрична й хімічна енергія, четвертого - атомна енергія та мікроелектронні компоненти, то п'ятого-інформація і знання, а шостого (перспективного) - нано- і клітинні технології. В залежності від ключових фракторів, кожен уклад накладає відбиток на структуру промисловості - через базові напрямки і види діяльності [4, с. 12; 5]:

- для III технологічного укладу - це сировинне та напівфабрикатне виробництво, традиційне паливо (газ і нафта), сталь, базова нафтохімія, інші корисні копалини; 
- для IV технологічного укладу - реактивне та турбореактивне літакобудування, атомне паливо, машинобудування, складна нафтохімія, складне конвейерне виробництво;

- для V технологічного укладу -електронна промисловість, комп'ютерні та інформаційні рішення, телекомунікації та автоматизація;

- для VI (перспективного) технологічного укладу - це наноелектроніка, молекулярна і нанофотоніка, "економіка вражень" (що орієнтується на відчуття споживача, його смаки, вподобання, емоції) тощо.

Для оцінювання технологічного рівня ВПД країни таїї регіонів слід взяти на озброєння Класифікацію виробничих структур ОЕСР [6], яка була прийнята в ЄС у 2007 р. Згідно 3 нею, еталонна (постіндустріальна) структура національної економіки, передусім промисловості, повинна мати такі частки ВПД різного технологічного рівня: високотехнологічних $-20 \%$, середньотехнологічних $-30 \%$, середньонизькотехнологічних $-20 \%$ і низькотехнологічних - 30\% [7, с. 96].

Високотехнологічні ВПД формують базис п'ятого технологічного укладу, середньотехнологічні -четвертого, а середньонизькотехнологічні і низькотехнологічні - переважно третього.

Дж. Лін [8] на прикладі китайської економіки довів, що національні економіки (зокрема, промисловий сектор. - В. З.), які мають прогресивнішу технологічну структуру (сучасну постіндустріальну), в загальному випадку мають і кращі можливості для подолання кризових явищ, зростання виробництва, зміцнення конкурентних позицій на міжнародних ринках. Це пояснюється тим, що домінування високотехнологічних ВПД дозволяє різко підвищити продуктивність праці і якість продукції, скоротити матеріало- та енергоємність товарного випуску.

Для досягнення позитивних зрушень у технологічній структурі промисловості країни та ії регіонів за співвідношеннями реалізованої продукції ВПД різного технологічного рівня, необхідно, щоб зрушення у цій структурі за відповідними співвідношеннями капітальних інвестицій були ще масштабнішими, інтенсивнішими.

Аналізу зрушень у технологічній структурі промисловості країни та її регіонів за відповідний період передбачає на першому етапі встановлення частки в ній певного ВПД або сегменту $\left(S_{i}\right)$ за обсягами реалізованої продукції (товарів, послуг) та капітальними інвестиціями. Ця частка обчислюється за такою формулою:

$$
S_{i}=a_{i} / \sum_{i=1}^{m} a_{i} \quad(i=\overline{1, m)},
$$

де $a_{i}$-обсяг реалізованої продукції (товарів, послуг) чи капітальних інвестицій $i$-го ВПД або сегменту промисловості у певному періоді (році), $m$ - кількість ВПД або сегментів промисловості.

Далі слід розрахувати індекс зміни частки ВПД або сегментів промисловості за певний період $\left(\mathrm{I}_{i}\right)$ :

$$
I u_{i}=\sum_{t=2}^{T}\left(S_{i 0}-S_{i t}\right): T, \quad(t=\overline{2, T})
$$

де $S_{i 0}$ - частка $i$-го ВПД або сегменту промисловості в базисному періоді (році); $S_{i t}-$ 
частка $i$-го ВПД або сегменту промисловості у кожному наступному (після базисного) періоді (році); $T$-кількість періодів (років).

Якщо йдеться про $/ \iota_{i}$ реалізованої продукції, то будемо його позначати як $I u_{i}^{P \Pi}$, якщо капітальних інвестицій-то як $I u_{i}^{K I}$.

Загальну оцінку досконалості (сучасності, прогресивності) технологічної структури промисловості можна дати на основі коефріцієнта Хечмена $\left(I_{\text {нАс }}\right)[9$, с. 16]:

$$
I_{H A C}=\frac{1}{\sum_{i=1}^{m}\left[\left(S_{i}^{N} / S_{i}^{E}\right) \times S_{i}^{N}\right]} \quad\left(0 \leq I_{H A C} \leq 1\right),
$$

де $S_{i}^{N}, S_{i}^{E}$ - частки $i$-х ВПД відповідно структури промисловості і еталонної структури.

Смисл варіації $I_{\text {нАс }}$ В інтервалі $[0,1]$ такий: при його значенні, що дорівнює одиниці, структура промисловості повністю співпадає з еталонною; нульове значення коефіцієнта свідчить про те, що ці структури абсолютно різні.

Коефріцієнт Хечмена за співвідношеннями часток реалізованої продукції ВПД різного технологічного рівня логічно позначати $I_{H A C}^{P \Pi}$, а за співвідношеннями часток капітальних інвестицій $-I_{H A C}^{K I}$.

Зміни у технологічній структурі промисловості України за 2010-2015 рр. розглянемо спершу за динамікою часток реалізованої продукції та капітальних інвестицій ВПД різного технологічного рівня й відповідного технологічного укладу (табл. 1).

Як видно з таблиці, частка ВПД $\vee$ технологічного укладу у промисловості України $€$ мізерною і тому незначне зростання $I u_{i}^{P I}(0,1 \%)$ при ще більшому зростанні $I u_{i}^{K I}(0,3 \%)$ не справляє вирішального впливу на постіндустріальний поступ української промисловості. Особливо негативною $є$ тенденція щодо скорочення частки високотехнологічного виробництва комп'ютерів, електронної і оптичної продукції (з 0,7\% у 2011 р. до 0,5\% у 2015 р. при $I u_{i}^{P \Pi}=-0,1 \%$ ); і це при тому, що немає зростання інвестицій у цей ВЕД.

В умовах, коли частка ВПД $\vee$ технологічного укладу $є$ незначною i, до того ж, повільно зростає, скорочення частки ВПД IV технологічного укладу у 2015 р. проти 2010 р. на 1,9 в. п. при нульовому $I u_{i}^{P I}$ і від'ємному $I u_{i}^{K I}(-2,1 \%)$ вказує на суттєве погіршення технологічної структури української промисловості. Якщо скорочення інвестицій у виробництво хімічних речовин і хімічної продукції ( $\left.I u_{i}^{K I}=-1,5 \%\right)$, враховуючи те, що його основу складає виробництво азотних добрив на основі дефріцитної в Україні сировини природного газу й аміаку, не $є$ критично значимим трендом, то скорочення часток капітальних інвестицій у машинобудування (крім виробництва транспортних засобів 3 $\left.I u_{i}^{P I}=0,2 \%\right)$ слід розглядати як особливо негативну тенденцію.

Свідченням погіршення технологічної структури промисловості України єй скорочення частки більш технологічних (середньонизькотехнологічних) ВПД III технологічного укладу $\left(I u_{i}^{P I}=-4,6 \%\right)$, що підтримується негативною динамікою капітальних інвестицій $\left(I u_{i}^{K I}=\right.$ $-7,4 \%)$. Особливо небажаним є від'ємний $I u_{i}^{K I}(-3,8 \%)$ у добувній промисловості, в якій конче необхідним $є$ збільшення обсягів видобування газу та вугілля, зокрема на підконтрольній Україні території. 
Національна і регіональна економіка

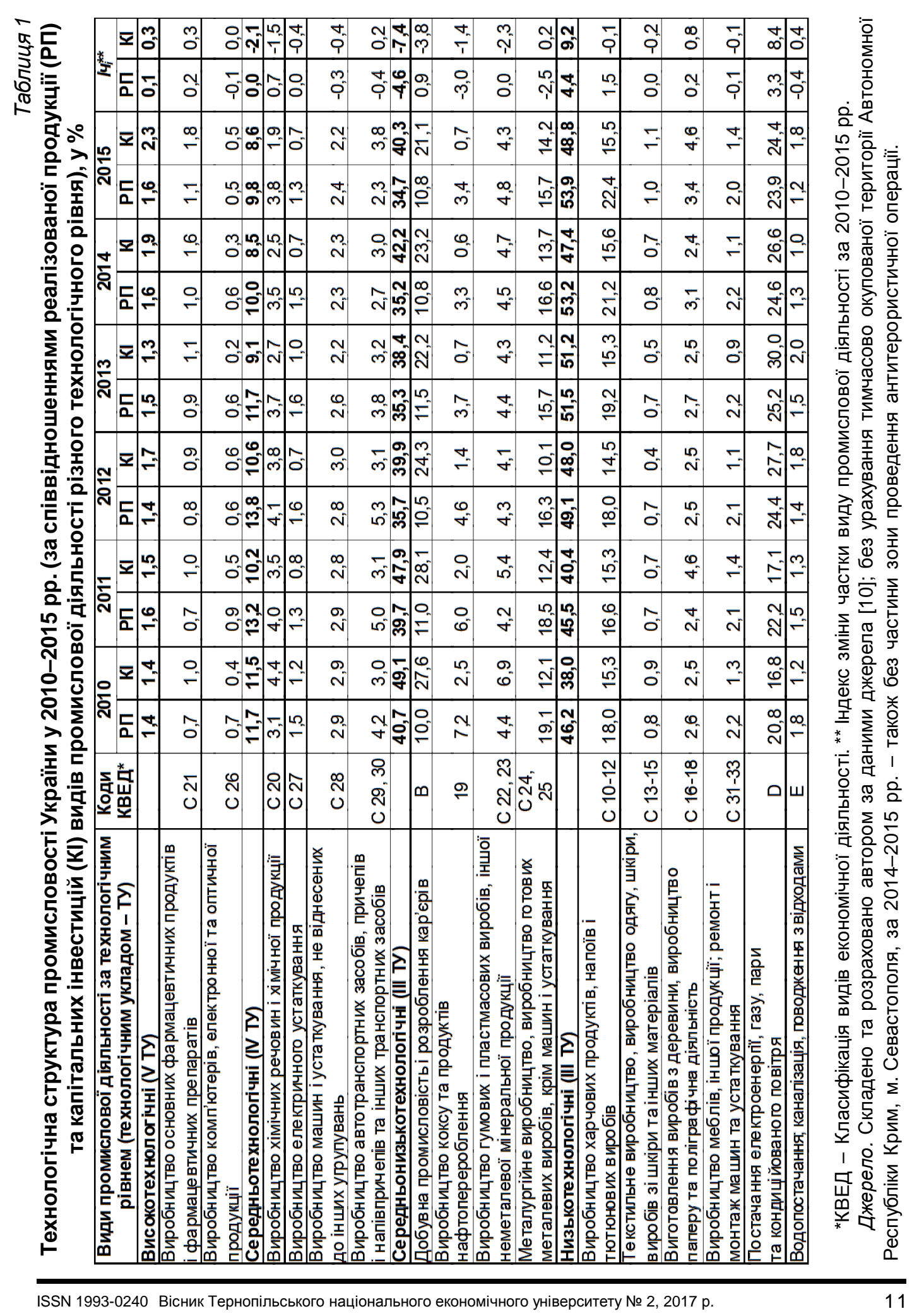


Щодо позитивної динаміки капітальних інвестицій у металургії ( $\left.I u_{i}^{K I}=0,2 \%\right)$ за від'ємного приросту реалізованої продукції ( $\left.I u_{i}^{P П}=-2,5 \%\right)$, то вона пояснюється насамперед переходом на киснево-конвертерний метод виплавляння сталі (замість мартенівського) та більш широким застосуванням технології безперервного розливу сталі.

Скорочення часток і реалізованої продукції, і капітальних інвестицій у середньонизькотехнологічних ВПД в основному перекрито за рахунок низькотехнологічних ВПД, які мають позитивну динаміку і за $I u_{i}^{P I}(4,4 \%)$, і за $I u_{i}^{K I}(9,2 \%)$, що загалом є негативним трендом. Водночас і в сегменті цих ВПД слід заохочувати збільшення капітальних інвестицій в окремі види діяльності, а саме: легкої промисловості, частка якої у обсязі реалізованої продукції є неприпустимо малою (менше 1\%); ВПД, які пов'язані 3 переробкою деревини, зокрема глибокою (з виготовлення ДВП, ДСП, меблів, паперу, картону тощо), яка передбачає створення ланцюгів доданої вартості; ВПД із водопостачання, каналізації та поводження з відходами, тому що досить багато великих населених пунктів не мають централізованого водопостачання та водовідведення, а ситуація з переробкою сміття взагалі є катастрофічною.

Щодо ВПД VI технологічного укладу, які в розвинутих країнах нині активно формуються, слід зауважити, що їх становлення у промисловості України - це далека перспектива.

Аналіз значень коефіцієнта Хечмена свідчать про те, що технологічна структура промисловості України сильно відрізняється (в гіршу сторону) від еталонної для країн ЄС як за співвідношеннями реалізованої продукції ВПД різного технологічного рівня, так і за співвідношеннями капітальних інвестицій (рис. 1).

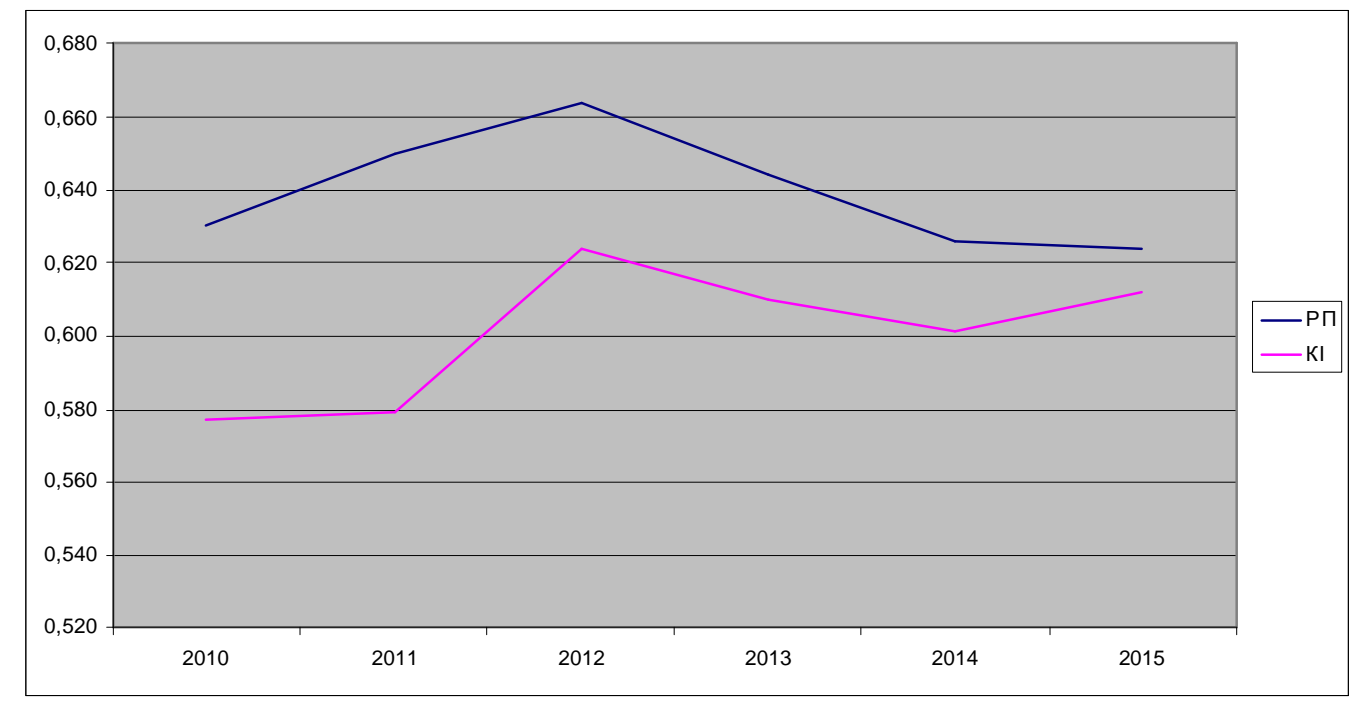

Рис. 1. Коефріцієнт Хечмена - відповідності технологічної структури промисловості України еталонній структурі країн ЄС у 2010-2015 рр., за співвідношеннями реалізованої продукції (РП) та капітальних інвестицій (КI) видів промислової діяльності різного технологічного рівня

Джерело. Побудовано автором за розрахунковими даними, одержаними на основі табл. 1. 
З рисунка видно, що тренди трансформації технологічної структури промисловості України за співвідношеннями реалізованої продукції та капітальних інвестицій ВПД різного технологічного рівня сильно корелюють між собою. У 2010-2012 рр. відмічалося поліпшення структурних характеристик промисловості України за обома співвідношеннями. У 2013 р. вони стала погіршуватися. Щоправда, у 2015 р. вдалося "переламати" негативні тенденції, зокрема у формуванні технологічної структури промисловості за співвідношеннями капітальних інвестицій. Відповідно, можна прогнозувати поліпшення технологічної структури промисловості і за співвідношеннями реалізованої продукції ВПД різного технологічного рівня.

Розрахунки $I u_{i}^{P I}$ та $I u_{i}^{K I}$ на регіональному рівні за тривалий період натикаються на певні методологічні труднощі, пов'язані з переходом у 2012 р. до КВЕД-2010, який дозволяє коректно простежити динаміку технологічної структури промисловості регіонів України тільки з 2013 р. (табл. 2).

Дані табл. 2 свідчать про те, що промислові виробництва високого технологічного рівня ( $\mathrm{V}$ технологічного укладу) у 2015 р. найбільшими були у структурі промисловості Закарпатської області (5,1\%), хоча проти 2013 р. їх частка скоротилася на 12,0 в. п. у зв'язку з падінням обсягів виробництво комп'ютерів, електронної та оптичної продукції на підприємствах з іноземним капіталом (ТОВ завод “Флекстронікс ТзОВ”, ТОВ “Джейбіл Сьоркіт Юкрейн Лімітед”, ПАТ “Мукачівський завод “Точприлад”). Водночас той факт, що ця область потіснила з першої позиції за часткою капітальних інвестицій Харківську область (14,8\% проти 9,3\%) вказує на те, що й надалі вона збереже лідируючі позиції в сегменті високотехнологічних ВЕД. Чільне місце в цьому сегменті ВПД посідає Черкаська область, в якій добре розвинена фрармацевтична промисловість (ПАТ "Вітаміни", м. Умань). До лідерів за часткою капітальних інвестицій у високотехнологічні ВЕД підтягнулася Одеська область (7,9\%), це вказує на те, що вона має можливість підвищити частку цих ВПД і за обсягами реалізованої продукції. Хоча й за часткою інвестицій столиця перемістилася 3 другої позиції на п'яту, та за часткою реалізованої продукції високотехнологічних ВПД, навпаки, піднялася з третього місця на друге. Точно вказати, які області у 2015 р. посідали останні місця за розвиненістю ВПД V технологічного укладу досить складно, тому що дані по фрармацевтичній промисловості по більшості регіонів складають комерційну таємницю. У 2013 р. найменша частка реалізованої продукції ВПД $\vee$ технологічного укладу $(0,1 \%)$ відмічалася у промисловості Дніпропетровської, Івано-Франківської та Миколаївської областей. Логічно допустити, що частка капітальних інвестицій у ВПД цього укладу в цих областях, як і в Херсонській, Кіровоградській та деяких інших, також $є$ найменшою.

На сьогодні передовими в технологічному відношенні є ті регіони, промисловість яких має найкраще розвинутий сегмент ВПД середньовисокого технологічного рівня (IV технологічного укладу), передусім, машинобудівних. Першу позицію за часткою реалізованої продукції цих ВПД (як і ВПД V технологічного укладу) утримує Закарпатська область (38,9\%), хоча вона й поступається за часткою капітальних інвестицій у їхній розвиток Запорізькій області. Водночас значне зростання капітальних інвестицій у виробництво транспортних засобів (на ПрАТ “Єврокар” у с. Соломоново, де збираються автомобілі марки Skoda) й зростання частки цього ВПД у загальному обсязі капітальних 


\section{Â. Çàò̇̀ั:åi ê}

Капітальні інвестиції як драйвер ...

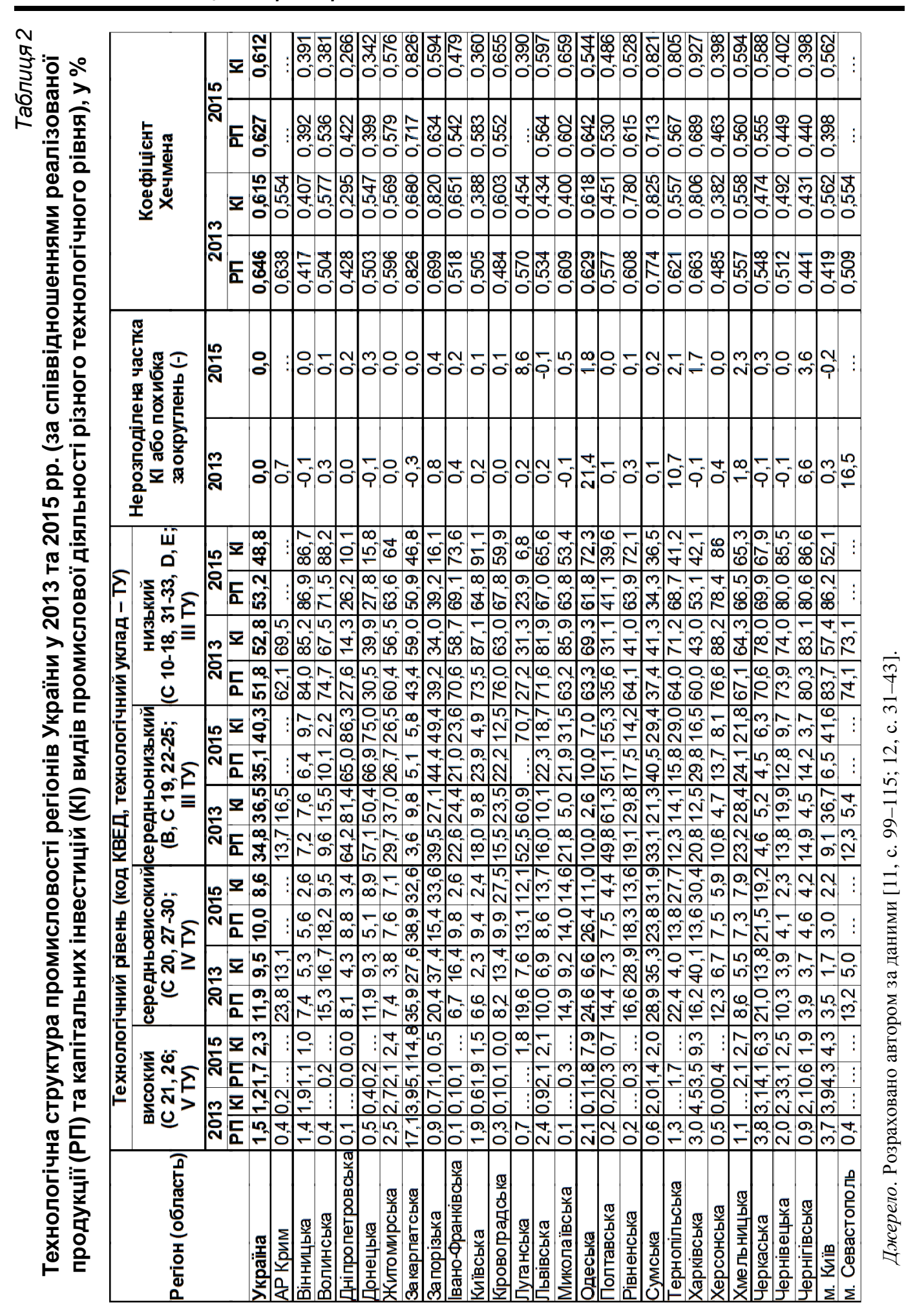


інвестицій (з 9,1\% у 2013 р. до 27,2\% у 2015 р.) можуть вивести Закарпатську область в лідери і за часткою капітальних інвестицій у розвиток ВПД IV технологічного укладу. Друге та третє місця за часткою реалізованої продукції цього сегменту промисловості займають Сумська і Одеська області, але якщо перша з них за часткою капітальних інвестицій стабільно знаходиться на третьому місці, то друга - навіть не входить до першої десятки. Найменше представлені ВПД IV технологічного укладу в промисловості м. Києва (3,0\%), Чернівецької та Чернігівської областей. І це цілком закономірно, оскільки вони не вирізняються значною часткою капітальних інвестицій у них. Потенціал промисловості Запорізької, Миколаївської, Рівненської та Хмельницької областей за ВПД IV технологічного укладу міг би бути більшим, якби до них віднести атомну енергетику, що включена до низькотехнологічних ВПД з постачання електроенергії, газу, пари та кондиційованого повітря. Як суттєву негативну тенденцію відмітимо досить різке скорочення частки ВПД IV технологічного укладу у промисловості Запорізької і Харківської областей, що не в останню чергу пов'язано із суттєвим скороченням їхніх часток за капітальними інвестиціями.

ВПД середньонизького технологічного рівня III технологічного укладу складають основу промисловості Дніпропетровської, Донецької, Запорізької і Луганської (видобування вугілля і залізної руди та металургійне виробництво), Полтавської (добувна промисловість й нафтоперероблення) та Сумської (добувна промисловість) областей. Вони є лідерами цього сегменту промисловості як за часткою реалізованої продукції, так і часткою капітальних інвестицій. Найменше представлений цей сегмент за часткою реалізованої продукції у Черкаській, Закарпатській та Вінницькій областях, а за часткою капітальних інвестицій - у Волинській, Чернігівській та Київській областях.

Найбільшу частку низькотехнологічних ВПД III технологічного укладу (понад 80\% обсягу реалізованої продукції) має промисловість м. Києва, Вінницької, Чернівецької та Чернігівської областей. Основним ВПД у них є виробництва харчових продуктів, напоїв і тютюнових виробів (Вінницька і Чернігівська області), постачання електроенергії, газу, пари та кондиційованого повітря (м. Київ та Чернівецька область). Однак за часткою капітальних інвестицій у розвиток низькотехнологічних ВПД тільки Вінницька область у трійці лідерів. Перші два місця належать Київській та Волинській областям. Найменші частки і реалізованої продукції, і капітальних інвестицій низькотехнологічних ВПД мають області з найбільшим представництвом ВПД середньонизького технологічного рівня.

Аналіз досконалості технологічної структури промисловості регіонів України за коефіцієнтом Хечмена показав, що найбільш досконалою за $I_{H A C}^{P I}$ вона була у 2015 р. у промисловості Закарпатської області $(0,717)$, хоча й погіршилася проти 2013 р. Пояснюється це тим, що у її структурі найвищою є частка ВПД V i IV технологічних укладів -44,0\%. Поліпшення структури промисловості області за $I_{H A C}^{K I}$ (перехід з п'ятої позиції у 2013 р. на другу у 2015 р.) вказує на те, що вона матиме позитивний тренд і за $I_{H A C}^{P I}$. Сумська область, яка стабільно займає другу позицію за $I_{H A C}^{P \Pi}(0,713)$, може поступитися нею третій у списку - Харківській області ( $\left.I_{H A C}^{K I}=0,689\right)$, тому що та 20132015 рр. поліпшила свою структуру за $I_{H A C}^{K I}(0,927)$ й вийшла за цим коефіцієнтом на 
перше місце. Найменш досконалу структури промисловості за $I_{H A C}^{P \Pi}$ мають такі регіони, як Вінницька, Донецька і Дніпропетровська області, та м. Київ. Усі вони, крім Києва, не вирізняються досконалістю структури і за $I_{H A C}^{K I}$, що пояснюється домінуванням інвестицій у один-два ВПД. Досить недосконалою є й структура промисловості Київської області, зокрема за $I_{H A C}^{K I}$, тому що в ній у 2015 р. 81,7\% інвестицій було спрямовано в енергетичний сектор.

Аналіз зрушень у технологічній реструктуризації промисловості України та її регіонів показав, що вона перебуває в ситуації, яку В. Ільченко назвав штопором "зворотньої тяги" технологічних укладів [5]. Це коли в структурі промисловості ВПД ІІІ технологічного укладу “виштовхують" з неї більш прогресивні ВПД IV i V укладів. Чому так відбувається? А тому, що недосконалими (антинародними) є соціально-політичні інститути суспільства, які дозволили владі небагатьох (олігархії) узурпувати власність народу на природні багатства, що об’єктивно вимагає розвитку ВПД ІІІ технологічного укладу.

Щоб протистояти цьому, має проводитися деолігархізація українського суспільства та виважена державна промислова політика. Головним завданням останньої має стати мобілізація інвестиційних ресурсів для досягнення таких структурних параметрів промисловості, які відповідають сучасним (постіндустріальним) стандартам розвинутих країн. Шляхів для цього багато. Одним із перспективних, на наш погляд, є транснаціоналізація української промисловості, яка дозволяє в значних обсягах залучати прямі іноземні інвестиції у розвиток новітніх ВЕД й таким чином модернізувати її структуру. На це, зокрема, вказує позитивний досвід технологічної реструктуризації промисловості Закарпатської області.

Висновки. Технологічна структура промисловості України та їі регіонів й досі формується переважно на основі ВПД III технологічного укладу. Виробництва четвертого, а тим більше п'ятого укладів представлені недостатньо. Отже, в постіндустріальну епоху трансформація технологічної структури промисловості країни та її регіонів є необхідною передумовою ефективного і динамічного зростання їхнього виробництва. Аби кардинально поліпшити ситуацію й наблизити технологічну структуру української промисловості до стандартів ЄС, необхідно наростити й перерозподілити капітальні інвестиції на користь ВПД новітніх технологічних укладів. Перші результати технологічного оновлення промисловості уже відчутні у Закарпатській області. Великий потенціал технологічної реструктуризації промисловості мають Харківська, Дніпропетровська, Запорізька й інші області та столиця країни.

Продовження досліджень у визначеному напрямку (за більший часовий відрізок) на основі глибшої диференціації ВПД за технологічними укладами дозволить виявити стійкі тренди в динаміці технологічної структури промисловості країни та її регіонів й коригувати їх завдяки адресним інвестиціям у новітні ВПД згідно з трендами постіндустріального розвитку.

\section{Список використаних джерел}

1. Bell D. The Coming of the Post-Industrial Society. - New York : Basic Books Corp., 1973. $-507 p$. 
2. Промислова політика посткризової економіки : кол. моногр. / Л. В. Дейнеко, М. М. Якубовський, Е. І. Шелудько [та ін.] ; за ред. Л. В. Дейнеко, М. М. Якубовського. - К. : Ін-т екон. та прогнозув. НАН України, 2014. - 316 c.

3. Пріоритети інвестииійного забезпечення структурних рефрорм у промисловості України : аналіт. доп. / О. В. Собкевич, А. В. Шевченко, А. І. Сухоруков, Є. В. Бєлашов. - К. : Нац. ін-т стратег. дослідж., 2014. - 57 с.

4. Нанотехнологии как ключевой фактор нового технологического уклада в экономике / под ред. С.Ю. Глазьева, В.В. Харитонова. - М. : Тровант, 2009. $304 \mathrm{c}$.

5. Ільченко В. Вийти зі штопора "зворотньої тяги" технологічних укладів [Електронний ресурс] // Uainfo. - 2016. - 20 липня. - Режим доступу : https:// uainfo.org/blognews/1469017264-viyti-zi-shtopora-zvorotnoyi-tyagi-tehnologichnihukladiv.html.

6. Isic Rev. 3 Technology Intensity Definition. Classification of manufacturing industries into categories based on R\&D intensities [Електронний ресурс] / OECD Directorate for Science, Technology and Industry. Economic Analysis and Statistics Division. 2011. - 7 July. - 7 p. - Режим доступу : https://www.oecd.org/sti/ind/48350231.pdf

7. Пирог О.В. Адаптація структури національної економіки України до вимог постіндустріального суспільства //Вісник Національного університету “Львівська політехніка": Проблеми економіки та управління. -2011. -№ 698. -С. 93-103.

8. Lin J. New structural economics: A Framework for Rethinking Development and Policy. Washington D.C. : The Word Bank, 2012. - 388 p.

9. Михеева Н. Н. Структурные фракторы региональной динамики: измерение и оценка // Пространственная экономика. -2013. - № 1. - С. 11-32.

10. Статистична інформація [Електронний ресурс] // Державна служба статистики України : офріu. сайт. - Режим доступу : http://www.ukrstat.gov.ua/.

11. Капітальні інвестиції в Україні у 2010-2015 роках : cmam. зб. / за ред. І. С. Петренко. -К. : Держслужба статистики України, 2016. - 115 с.

12. Промисловість України у 2010-2015 роках: стат. зб. / за ред. І. С. Петренко. К. :Держслужба статистики України, 2016. - 381 с.

\section{References}

1. Bell D. The Coming of the Post-Industrial Society. New York: Basic Books Corp., 1973, 507 p. [in English].

2. Deineko L.V., Yakubovskyi M.M., Sheludko E.I. Promyslova polityka postkryzovoi ekonomiky: kol. monohr. [Industrial policy of post-crisis economy: collective monograph]. Kyiv: In-t ekon. ta prohnozuv. NAN Ukrainy, 2014, 316 p. [in Ukrainian].

3. Sobkevych O.V., Shevchenko A.V., A. I. Sukhorukov A.I. et al. Priorytety investytsiinoho zabezpechennia strukturnykh reform u promyslovosti Ukrainy [Priorities of investment support for structural reforms in Ukraine's production sector: analytical report]. Kyiv: Nats. in-t strateh. doslidzh., 2014, 57 p. [in Ukrainian].

4. Glazev D.Yu., Kharitonov V.V Nanotekhnologii kak kliuchevoi faktor novogo tekhnologicheskogo uklada $v$ ekonomike [Nanotechnology as a key factor in the new technological mode of economy]. M. : Trovant, 2009, 304 p. [in Russian]. 
5. Ilchenko V. Vyity zi shtopora "zvorotnoi tiahy" tekhnolohichnykh ukladiv [How to spin off "the back-draught" of technological modes], from https://uainfo.org/blognews/1469017264viyti-zi-shtopora-zvorotnoyi-tyagi-tehnologichnih-ukladiv.html [in Ukrainian].

6. Isic Rev. 3 Technology Intensity Definition. Classification of manufacturing industries into categories based on R\&D intensities, from https://www.oecd.org/sti/ind/48350231.pdf [in English].

7. Pyroh O.V. Adaptatsiia struktury natsionalnoi ekonomiky Ukrainy do vymoh postindustrialnoho suspilstva [Adapting the structure of Ukraine's national economy to the requirements of post-industrial society]. Visnyk Natsionalnoho universytetu "Lvivska politekhnika": problemy ekonomiky ta upravlinnia - Bulletin of Lviv Polytechnic National University: issues of economy and management, 2011, No. 698, pp. 93-103 [in Ukrainian].

8. Lin J. New structural economics: A Framework for Rethinking Development and Policy. Washington D.C.: The Word Bank, 2012, 388 p. [in English].

9. Mykheeva N. N. Strukturnye faktory regionalnoi dinamiki: izmerenie i otsenka // Prostranstvennaia ekonomika - Spatial economics, 2013, No. 1, pp. 11-32 [in Russian].

10. Statystychna informatsiia, from http://www.ukrstat.gov.ua/ [in Ukrainian].

11. Kapitalni investytsii v Ukraini u 2010-2015 rokakh: stat. zb. [Capital investments in Ukraine in 2010-2015: statistics digest]. Kyiv: Derzhsluzhba statystyky Ukrainy, 2016, 115 p. [in Ukrainian].

12. Promyslovist Ukrainy u 2010-2015 rokakh: stat. zb. [Ukraine's industry in 2010-2015: statistics digest]. Kyiv: Derzhsluzhba statystyky Ukrainy, 2016, 381 p. [in Ukrainian].

Редакція отримала матеріал 20 березня 2017 р. 